TAPROBANICA, ISSN 1800-427X. November, 2020. Vol. 09, No. 02: pp. 232-236, pl. 65-66.

(C) Research Center for Climate Change and Department of Biology, Faculty of Mathematics \& Natural Sciences, University of Indonesia, Depok 16424, INDONESIA.

http://www.taprobanica.org/

https://doi.org/10.47605/tapro.v9i2.239

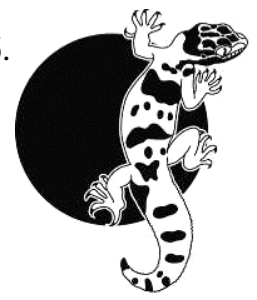

\section{Lesser large-footed Bat (Myotis hasseltii) from Southwest Sri Lanka}

The Lesser large-footed bat, Myotis hasseltii, is distributed in Sri Lanka, India (West Bengal) and Southeast Asia including Myanmar, Thailand, Cambodia, Viet Nam, Peninsular Malaysia, Indonesia, and China (Phillips 1935, 1980, Bates \& Harrison 1997, Menon 2003, Zhang et al. 2004, Francis 2008, Huang et al. 2014, Bates et al. 2020). Although the Global Red List of IUCN categorized this species as of Least Concern (Bates et al. 2020), the National Red List of Sri Lanka lists it as Near Threatened (IUCN-MOE 2012). Myotis hasseltii is a relatively rare bat species in Sri Lanka, and has a patchy distribution there with the few previous locality records coming from the northern, eastern and southern parts of the dry zone of the island (Bates \& Harrison 1997, Molur et al. 2002, Yapa 2017). Earlier records of this species are from Anuradhapura, Kappachchi, Kokoputchi, Valaichchenai and Yala National Park (Phillips 1935, 1980, Molur et al. 2002), Minipe Canal near Randenigala (Yapa et al. 2006, Yapa \& Ratnavira 2013) and Thelgamuwa Oya near Illukkumbura in the Knuckles region (Wellappulli-Arachchi et al. 2014). Here, we provide the first record of $M$. hasseltii from the Southwestern wet zone of Sri Lanka (Sabaragamuwa Province).

The range extension is from the vicinity of an ancient Buddhist monastery, Bambaragala Aranya Senasanaya $\left(6.512750^{\circ} \mathrm{N}, 80.748667^{\circ}\right.$ E, alt. $\sim 150 \mathrm{~m}$ a.s.l.) in Pallebedda, Ratnapura District in Sabaragamuwa Province, Sri Lanka (Fig. 1). The locality is in the lowland intermediate bio-climatic zone (annual mean rainfall is $1500-2000 \mathrm{~mm}$ and temperature is $\left.27.8-29.6{ }^{\circ} \mathrm{C}\right)$. Visual encounter surveys were carried out for a period of six days (25-30 July 2016) in dry-mixed evergreen forests in the monastery grounds involving 4 trained field biologists, during both the day (08:00-14:00 h) and night (18:00 -21:30 h).

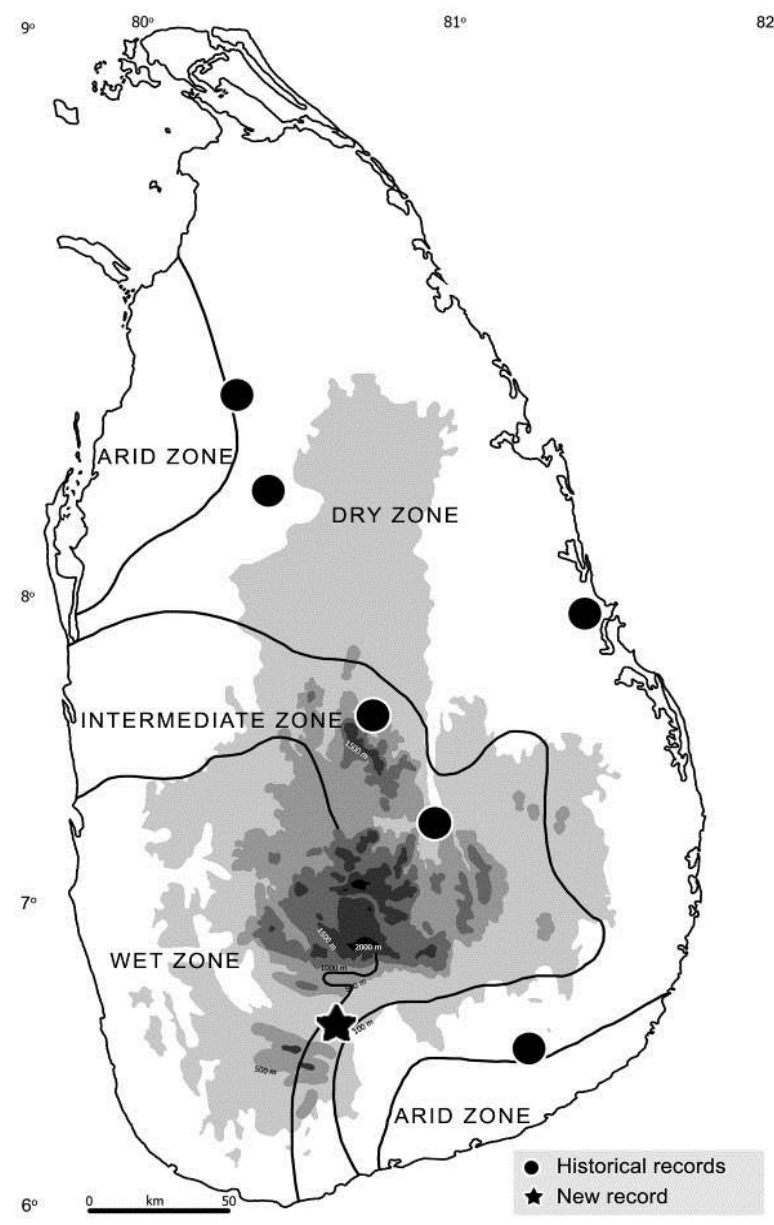

Figure 1. Distribution of Myotis hasseltii in Sri Lanka. Historical locations are based on Phillips (1935, 1980), Molur et al. (2002), Yapa et al. (2006), Yapa \& Ratnavira (2013), Wellappulli-Arachchi et al. (2014); Map @ A A.A.T. Amarasinghe

Microbats encountered at the site were captured using hand nets (depth: $45 \mathrm{~cm}$, diameter: $30 \mathrm{~cm}$, mesh size: $1.5 \times 1.5 \mathrm{~mm}$ ). For all bats captured, standard length measurements (following Srinivasulu et al. 2010) were taken using digital vernier calipers (Type RD 10) in the field. Morphological characteristics and body coloration were also documented. The captured bats were identified to the species level based on Phillips (1935), Corbet \& Hill (1992), Bates \& Harrison (1997), and Srinivasulu et al. (2010), prior to releasing. Air temperature and relative humidity were measured using a multi- 
digital hygrometer (TA-138, China), and wind speed using a digital anemometer (MS-6252-A, China). A Garmin Etrex handheld GPS receiver was used to georeference the roosting sites.

A colony of eight individuals of $M$. hasseltii was observed roosting in a hole in a decaying Arjun tree ("kumbuk"), Terminalia arjuna (Combretaceae). The roosting site was in riverine forest and had a canopy cover of about $75 \%$. The hole was $60 \times 6 \mathrm{~cm}$ at the opening. The bats left the roosting site around 18:3519:14 $\mathrm{h}$ for foraging and were seen flying about a meter above the ground or lower. Other species such as Eastern bent-wing bat (Miniopterus fuliginosus), Rufous horseshoe bat (Rhinolophus rouxii), and Schneider's leaf-nosed bat (Hipposideros speoris) were also seen foraging in the same area. A new record of Round-eared tube-nosed Bat (Murina cyclotis) was also found from the same location (see Edirisinghe et al. 2020a). The morphometric variables and morphological characteristics are provided in Tables 1 and 2 . Two distinct colour variations were observed in the individuals we measured in the colony: grayish brown dorsal fur shaded in to light grayish yellow ventrally
(Fig. 2); and golden brown dorsal fur shaded in to brighter yellow ventrally (Fig 3).

In general, this bat is known to prefer aquatic and wetland habitats for foraging, as open water habitats present uncluttered space for echolocation along with food resources in high abundance. In South Asia, this species is mostly found in dry tropical seasonal forests. In Malaysia, animals are also known to forage in mangrove vegetation (Bates \& Harrison 1997). In Sri Lanka, they have been observed flying low, above the surface of irrigation tanks and rivers hunting for gnats, mosquitoes, and small flies that occur commonly in such environments (Bates \& Harrison 1997, Yapa \& Ratnavira 2013).

Our observations also confirmed their preference for foraging in riverine vegetation (Fig. 4). Bats are also known to use riparian corridors for navigation, particularly when flying between different roosting sites. Although caves and similar subterranean environments are widely used by Myotis congenerics for roosting, use of hollow trees, rock crevices and structures erected by people are also known as alternative sites (Nowak 1991).

Table 1. Morphometric variables recorded from Myotis hasseltii specimens from Bambaragala Aranya Senasanaya, Sri Lanka (measurements in mm; — not measured).

\begin{tabular}{|c|c|c|c|c|}
\hline \multirow{3}{*}{ Measurement } & \multicolumn{4}{|c|}{ Colouration (This study) } \\
\hline & & & gray to light gold & golden brown \\
\hline & Male & Female & Male & Male \\
\hline Head \& Body length & 52.80 & 49.9 & 57.13 & 48.93 \\
\hline Ear length & 16.42 & 15.67 & 15.30 & 16.25 \\
\hline Ear width & 7.00 & 7.02 & 6.67 & 7.52 \\
\hline Tragus length & 7.26 & 5.93 & 7.50 & 5.09 \\
\hline Tragus width & 1.75 & 1.77 & 1.77 & 1.37 \\
\hline Forearm length & 39.41 & 37.47 & 40.82 & 39.61 \\
\hline $1 \mathrm{mt}$ thumb $+1^{\text {st }}$ claw length & 6.77 & 6.57 & 6.65 & 07.54 \\
\hline $2^{\text {nd }}$ metacarpal & 39.13 & 36.39 & 41.27 & 37.12 \\
\hline $3^{\text {rd }}$ metacarpal & 38.40 & 38.04 & 40.43 & 38.45 \\
\hline $4^{\text {th }}$ metacarpal & 36.51 & 36.49 & 49.13 & 36.44 \\
\hline $5^{\text {th }}$ metacarpal & 37.72 & 35.95 & 37.76 & 37.29 \\
\hline $1 \mathrm{ph} 3 \mathrm{mt}$ length & 14.70 & 15.02 & 15.24 & 13.79 \\
\hline $2 \mathrm{ph} 3 \mathrm{mt}$ length & 19.96 & 19.90 & 20.82 & 18.98 \\
\hline $1 \mathrm{ph} 4 \mathrm{mt}$ length & 10.38 & 10.43 & 10.34 & 10.19 \\
\hline $2 \mathrm{ph} 4 \mathrm{mt}$ length & 10.54 & 11.52 & 11.23 & 10.58 \\
\hline $1 \mathrm{ph} 5 \mathrm{mt}$ length & 11.06 & 10.04 & 9.07 & 9.37 \\
\hline 2ph 5mt length & 10.82 & 11.69 & 9.39 & 7.71 \\
\hline Wingspan length & 280.0 & 280.0 & 280.0 & 280.0 \\
\hline Penis length & 3.31 & - & 4.20 & 2.96 \\
\hline Tibia length & 16.93 & 18.79 & 17.50 & 17.55 \\
\hline Calcar length & 21.82 & 23.57 & 22.04 & 23.24 \\
\hline Hind foot length & 8.96 & 12.74 & 10.30 & 9.70 \\
\hline Tail length & 37.83 & 37.46 & 37.40 & 39.87 \\
\hline
\end{tabular}




\section{Plate 65}
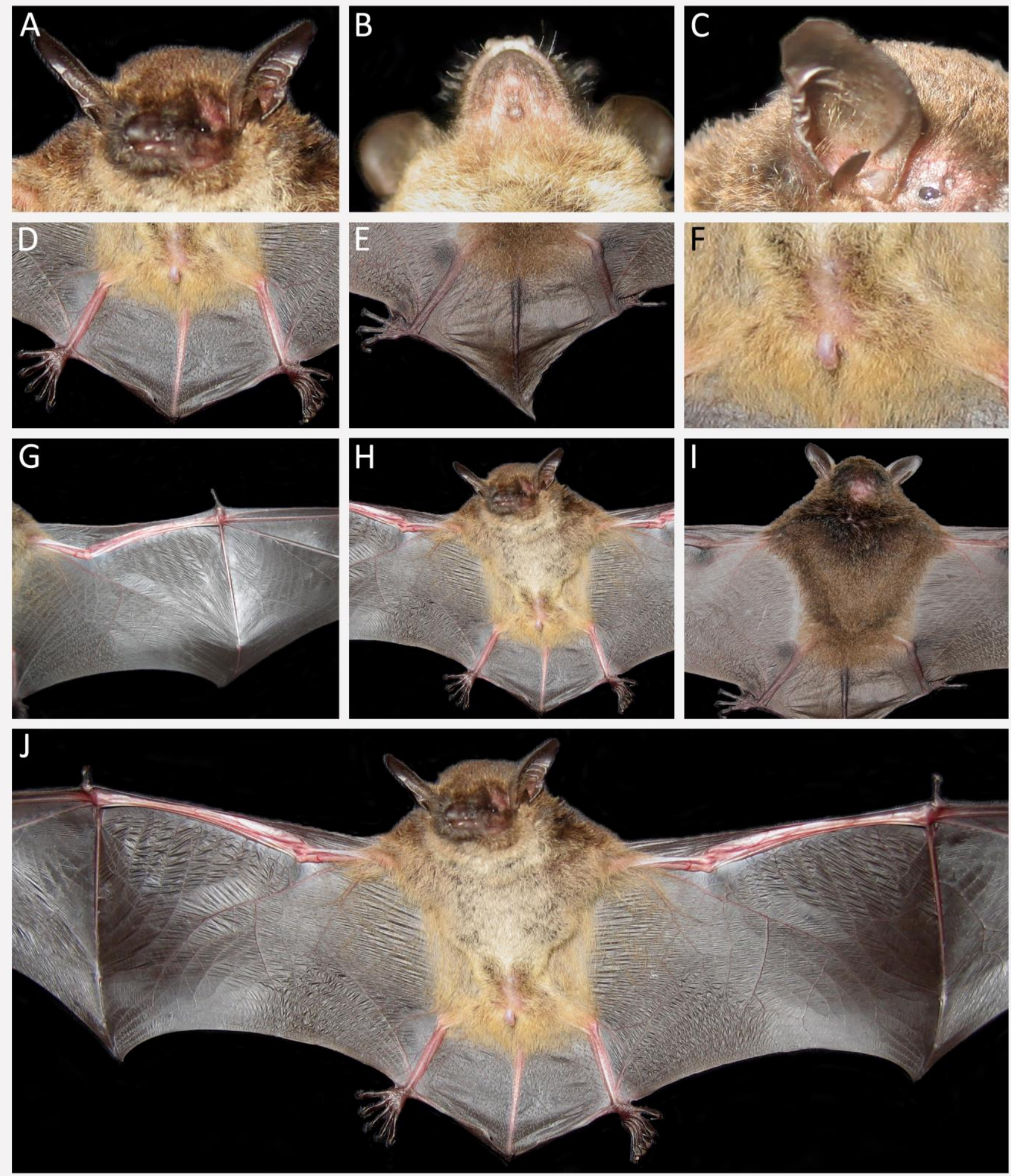

Figure 2. Unique characters of Myotis hasseltii specimen (a male with grayish yellow colouration) recorded from Bambaragala, Sri Lanka:(A) facial structure, (B) throat area [see the fur colour], (C) external ear lobe and tragus; (D) ventral and (E) dorsal aspects of the semitransparent interfemoral (tail) membrane, (F) short grayish yellow colour hairs around penis and the scrotum, (G) ventral aspect of the wing membrane (patagium); (H) ventral and (I) dorsal aspects of the body including the proximal parts of the patagium, (J) ventral aspect of expanded wings 


\section{Plate 66}
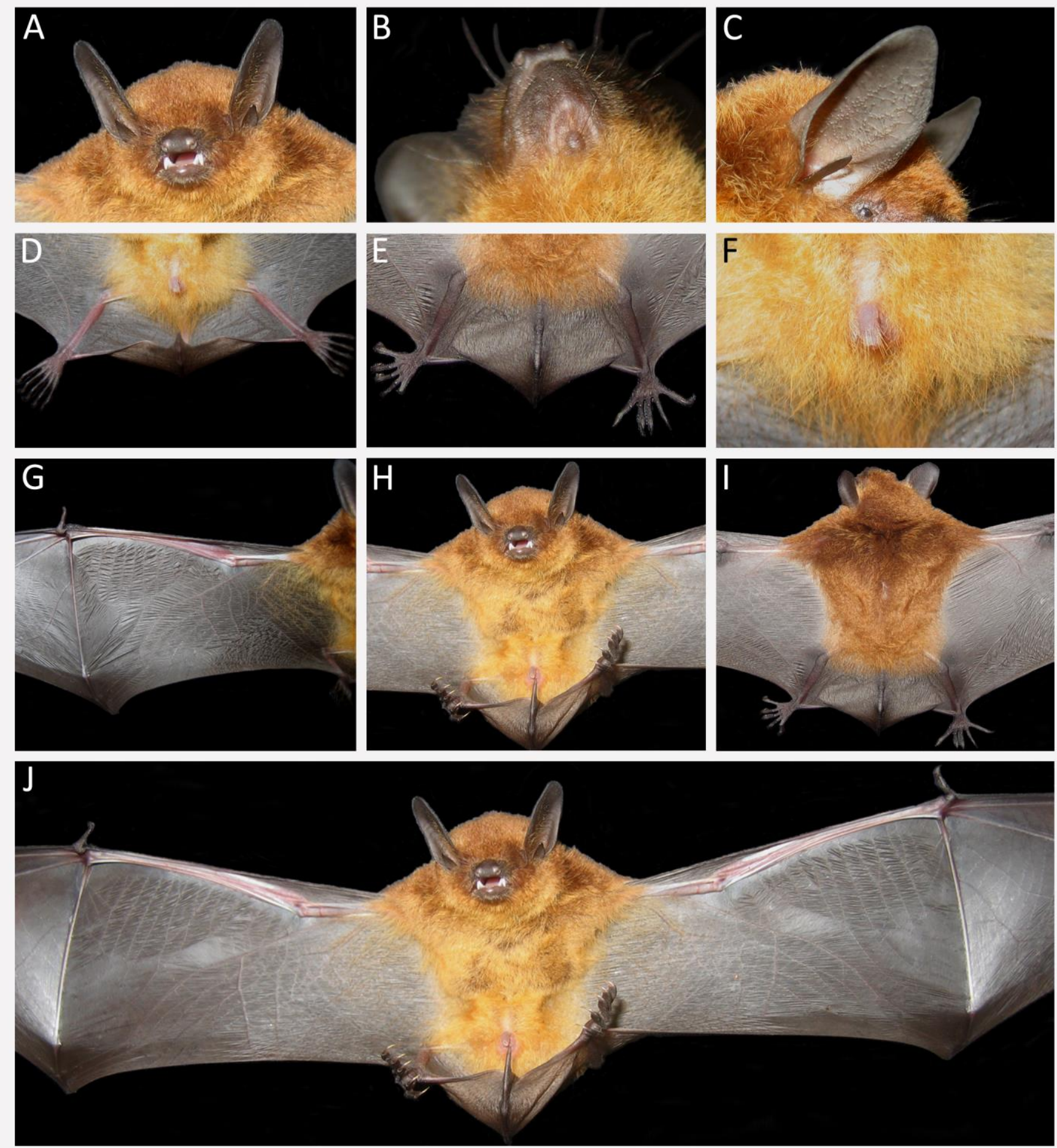

Figure 3. Unique characters of Myotis hasseltii specimen (a male with golden brown colouration) recorded from Bambaragala, Sri Lanka:(A) facial structure, (B) throat area [see the fur colour], (C) external ear lobe and tragus; (D) ventral and (E) dorsal aspects of the semitransparent interfemoral (tail) membrane, (F) short golden brown colour hairs around penis and the scrotum, (G) ventral aspect of the wing membrane (patagium); (H) ventral and (I) dorsal aspects of the body including the proximal parts of the patagium, (J) ventral aspect of expanded wings 


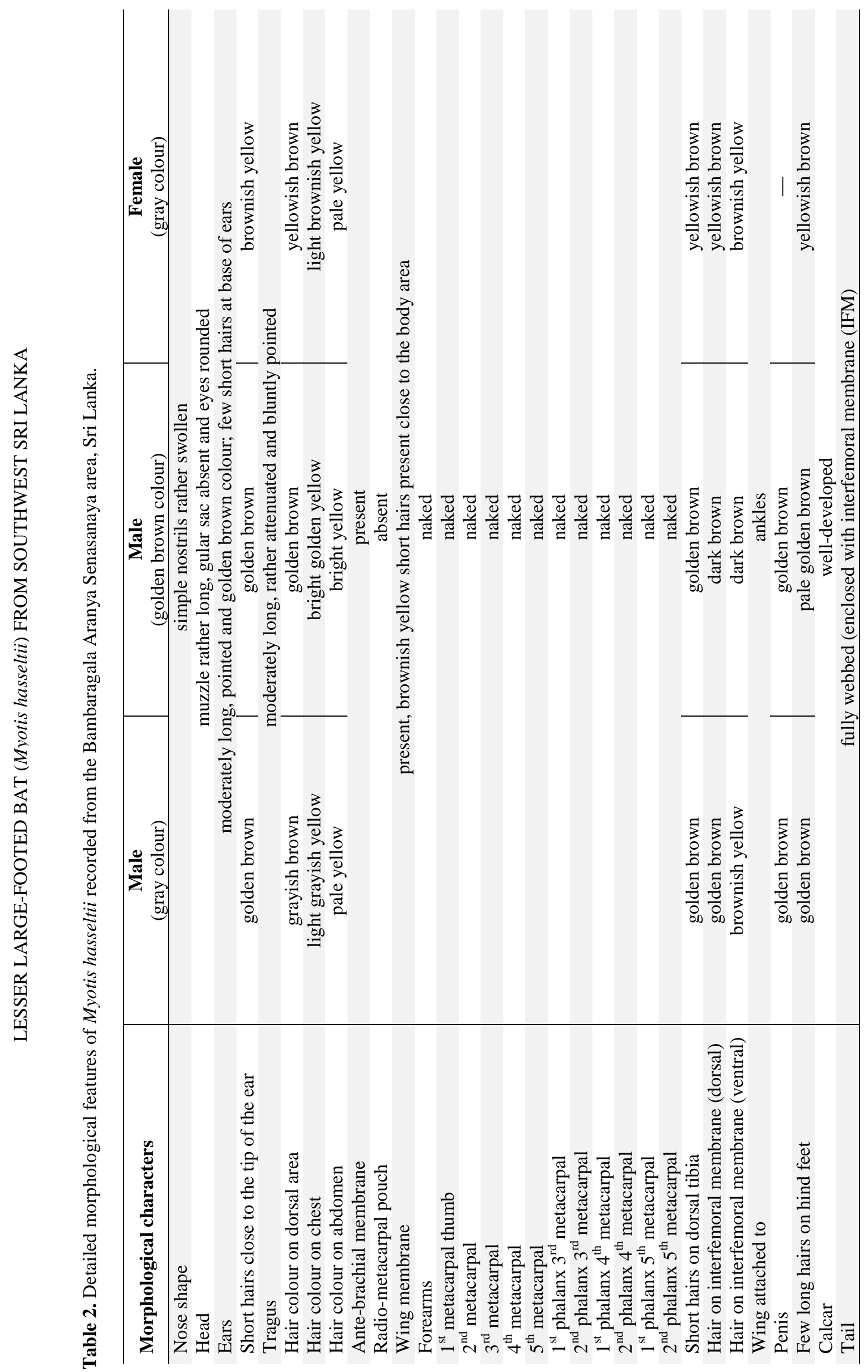




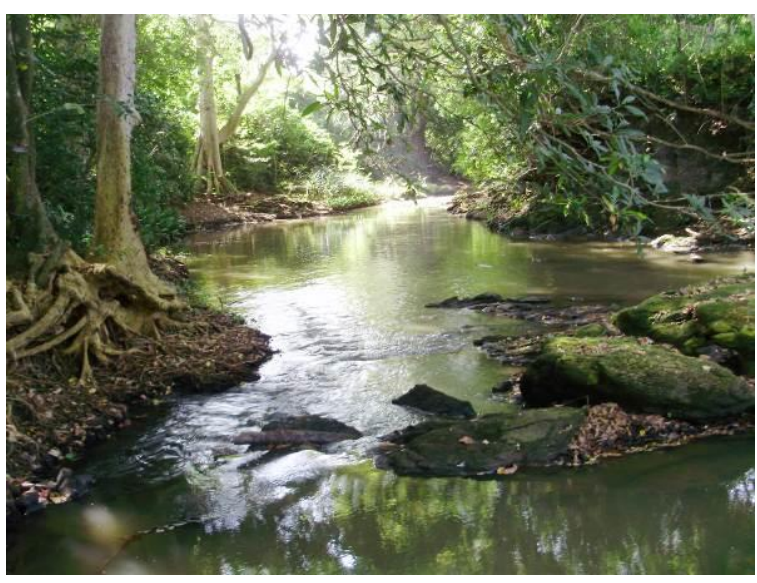

Figure 4. The riverine habitat of Myotis hasseltii in Bambaragala, Sri Lanka

M. hasseltii had been previously recorded roosting either singly or in small groups, in caves, cracks in tree-trunks or bamboo, crevices in rock outcrops, and fissures in abandoned buildings or archaeological ruins (Phillips 1935, Bates \& Harrison 1997, Francis 2008). Our observation of this particular roosting site is also in accordance with previously published literature. The locality we reported herein retained much natural land-cover, but has undergone anthropogenic modification with construction and subsequent management of the monastery, which is occupied by people. This bat species has also been recorded from developed landscapes - such as suburbs of Hanoi in northern Vietnam - and is known to benefit from access to large water bodies. However, the bat colony (Fig. 5) which was discovered (in 2012) beneath the bridge of Thelgamuwa Oya on the Raththota-Pallegama road near Ilukkumbura (Wellappulli-Arachchi et al. 2014) disappeared when the new bridge was built, and the roosting site was completely destroyed (Fig. 6A-B).

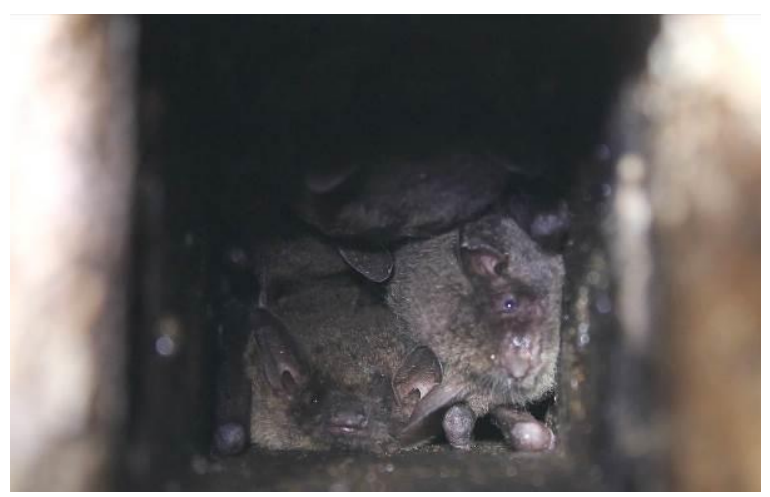

Figure 5. The roosting site of Myotis hasseltii beneath the bridge of Thelgamuwa Oya on the Raththota-Pallegama road near Ilukkumbura (first recorded by Wellappulli-Arachchi et al. 2014).
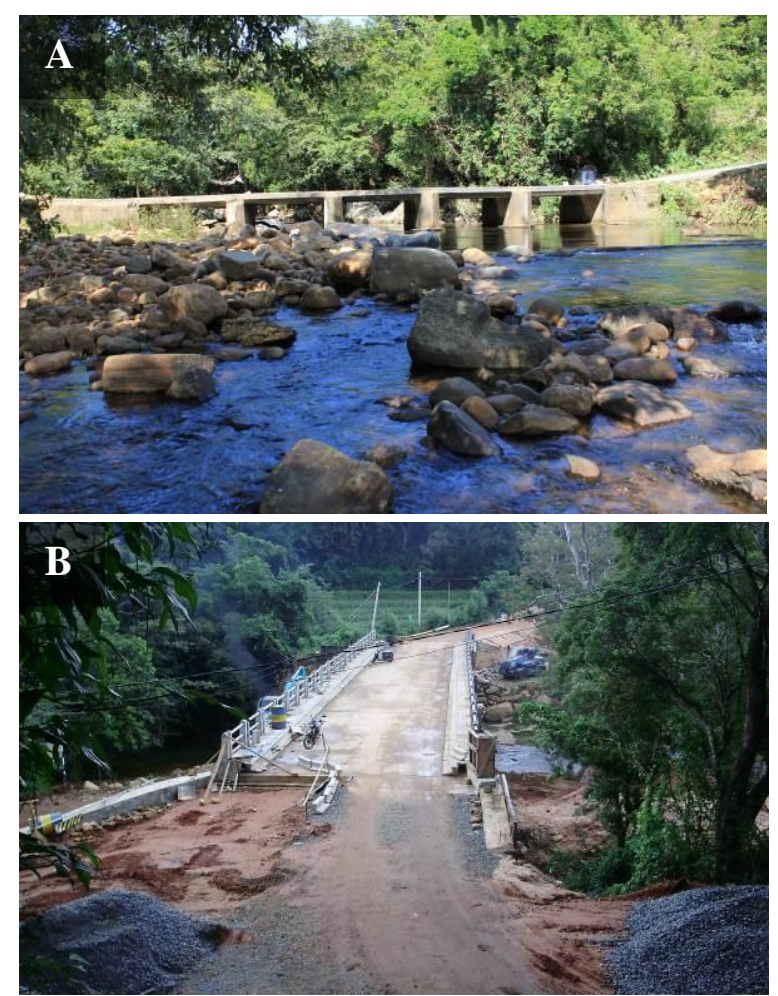

Figure 6. The bridge of Thelgamuwa Oya (A) old bridge in 2012 where Myotis hasseltii colony was found; (B) the new bridge in 2019, the roosting site was destroyed and no bats were recorded.

The distribution and conservation status of most of the Sri Lankan chiropterans, the echolocating microbats in particular, is poorly known. Exploring remote localities in Sri Lanka for bats can help fill-in these knowledge gaps, and thereby consolidate their distributional ranges and improve our understanding of their habitat associations (Nanayakkara et al. 2012, Edirisinghe et al. 2013, 2020a-b, WellappulliArachchi et al. 2014). Both systematic field surveys and opportunistic excursions can contribute to developing spatially explicit data and maps on the distribution patterns of Sri Lankan bats, which is imperative for successful conservation efforts.

\section{Acknowledgements}

We thank Ven. Weherawaththe Indrasumana Thero (chief incumbent) and other reverend theros of Bambaragala Monastery, Naveen Kumara, Dammika Wijesinghe and villagers for their support during field work. Also, we thank Burton Lim (Royal Ontario Museum, Canada), Thasun Amarasinghe (University of Indonesia), Suranjan Karunarathna ((NEET, Sri Lanka), and Philip Bowles (IUCN) for constructive comments that helped to improve the manuscript. 


\section{Literature cited}

Bates, P.J.J. and D.L. Harrison (1997). Bats of the Indian Subcontinent. Harrison Zoological Museum, Kent: 258pp.

Bates, P.J.J., A.M. Hutson, A. Carino, T. Kingston, B.P.Y-H. Lee et al. (2020). Myotis hasseltii. The IUCN Red List of Threatened Species 2020: e.T14164A22056644.

Corbet, G.B. and J.E. Hill (1992). The mammals of the Indomalayan Region: a systematic review. Natural History Museum Publications, Oxford University Press: 488pp.

Edirisinghe, G.M., B.S.A.T.H. Sudasinghe, and Y. Mapatuna (2013). Evidence of Saccolaimus saccolaimus (Chiroptera) roosting in a building in Sri Lanka. Taprobanica, 5 (1): 9496.

Edirisinghe, G., D. Gabadage, M. Botejue, P. Chandika \& T. Surasinghe (2020a). Roundeared tube-nosed Bat (Murina cyclotis) from Southwest Sri Lanka. Taprobanica, 9 (2): 227-231.

Edirisinghe, G., S. Akmeemana, S. Yaddehige, D. Gabadage, M. Botejue et al. (2020b). Chocolate pipistrelle (Hypsugo affinis) from Hantana, Sri Lanka after 87 years. Taprobanica, 9 (2): 237-241.

Francis, C.M. (2008). A Field Guide to the Mammals of South East Asia. New Holland Publishers, UK: 392pp.

Huang, J.C.-C., E. L. Jazdzyk, M. Nusalawo, I. Maryanto, S. Wiantoro et al. (2014). A recent bat survey reveals Bukit Barisan Selatan Landscape as a chiropteran diversity hotspot in Sumatra. Acta Chiropterologica, 16 (2): 413449.

IUCN-MOE (2012). The National Red List 2012 of Sri Lanka: Conservation Status of the Fauna and Flora. Ministry of Environment, Colombo, Sri Lanka: 476pp.

Menon, V. (2003). A Field Guide to Indian Mammals. Dorling Kindersley (India) Pvt. Ltd.: 201pp.

Molur, S., G. Marimuthu, C. Srinivasulu, S. Mistry, A.M. Hutson et al. (eds.) (2002). Status of South Asian Chiroptera: Conservation Assessment and Management Plan (C.A.M.P.) Workshop Report, 2002. Zoo Outreach Organisation, CBSG South Asia and WILD, Coimbatore: 320pp.

Nanayakkara, R.P., N. Vishvanath, and T.G.T. Kusuminda (2012). Re-discovery of pouch bearing sheath tailed bat Saccolaimus saccolaimus Temminck (Chiroptera: Emballonuridae) from Sri Lanka after 75 years. Asian Journal of Conservation Biology, 1 (2): $134-137$.
Nowak, R.M. (1991). Walker's Mammals of the World Fifth Edition Volume 1, The Johns Hopkins University, Maryland: 657pp.

Phillips, W.W.A. (1935). A Manual of the Mammals of Ceylon. Dulau \& Company, London: 373pp.

Phillips, W. W. A. (1980). Manual of the Mammals of Sri Lanka - Part 1, 2nd Revised Edition., Wildlife and Nature Protection Society of Sri Lanka, Colombo: 267pp.

Srinivasulu, C., P.A. Racey, and S. Mistry (2010). A key to the bats (Mammalia: Chiroptera) of South Asia. Journal of Threatened Taxa, 2 (7): 1001-1076.

Wellappulli-Arachchi, S.M., W.G.M. Edirisinghe, D.S.B. Dissanayake, Y. Mapatuna, and S. Wickramasinghe (2014). A breeding colony of the brown bat (Myotis hasseltii) from Sri Lanka. Taprobanica, 6 (1): 68-71.

Yapa, W. (2017). A Field Guide to the Bats of Sri Lanka. Dilmah Ceylon Tea Company PLC, Colombo, Sri Lanka: 142pp.

Yapa, A. and G. Ratnavira, 2013. The Mammals of Sri Lanka. Field Ornithology Group of Sri Lanka, University of Colombo, Colombo, Sri Lanka: 1009pp.

Yapa, W.B., W.L.P.T. S. de A. Goonatilake, P.O. Nameer, R. Marimuthu, and B.A. Daniel (2006). Report on the training in field techniques for the study of volant and nonvolant small mammals, Randenigala, Sri Lanka. Bat Net - CCINSA Newsletter, 7 (1-2): 3-8.

Zhang, L.-b., J.-s. Zhang, B. Liang, and S.-y. Zhang (2004). New record of a bat species from China, Myotis hasseltii (Temminck, 1840). Zoological Research, 25 (6): 556-559.

Submitted: 12 June, Accepted: 30 September 2020 Section Editor: Burton Lim

G. Edirisinghe ${ }^{1,6}$, D. Gabadage ${ }^{1}$, M. Botejue ${ }^{1,5}$, D. Dissanayake ${ }^{2}$, P. Chandika ${ }^{3} \&$ T. Surasinghe ${ }^{4}$

\footnotetext{
${ }^{1}$ Biodiversity Conservation Society, 150/6, Stanly Thilakaratne Mw., Nugegoda 10250, Sri Lanka ${ }^{2}$ Institute for Applied Ecology, University of Canberra, ACT 2601, Australia

${ }^{3}$ Hatangala, Balangoda 70100, Sri Lanka.

${ }^{4}$ Department of Biological Sciences, Bridgewater State University, Bridgewater, MA 02325, USA

${ }^{5}$ Central Environmental Authority, 104, Denzil Kobbekaduwa Mw., Battaramulla 10120, Sri Lanka

${ }^{6}$ E-mail: gayan.yza@gmail.com
}

Published date: 28 November 2020 